\title{
Potential Anti-Microbial, Anti-Inflammatory and Anti-Oxidant Activities of Haplophyllum tuberculatum Growing in Libya
}

Omar M Sabry ${ }^{1 *}$, Abeer M El Sayed ${ }^{1}$ and Amany A Sleem ${ }^{2}$

${ }^{1}$ Pharmacognosy Department, College of Pharmacy, Cairo University, Egypt

${ }^{2}$ Department of Pharmacology, National Research Centre, Cairo, Egypt

\begin{abstract}
Ethanolic extract of the aerial parts of Haplophyllum tuberculatum demonstrated an efficient anti-fungal activity against Aspergillus fumigates, Geotricum candidum and Syncephalastrum racemosum with (MIC 0.49, 0.12 and $1.95 \mu \mathrm{g} / \mathrm{ml}$ ). It also presented $75 \%$ potency as antibacterial agent on Staphylococcus aureus and Escherichia coli (MIC 1.95 and $15.63 \mu \mathrm{g} / \mathrm{ml}$ ). Volatile oil of the aerial parts demonstrated significant antibacterial effect against Enterococcus faecalis and Lactobacillus acidophilus (MIC 1.95 and $0.98 \mu \mathrm{g} / \mathrm{ml}$ ). The essential oils from aerial parts and flowers exhibited a remarkable acute anti-inflammatory activity against carrageenan induced oedema in rats $9.52 \%$ and $8.56 \%$ which were found to be comparable to the standard drug at the selected dose. The ethanolic extract of the aerial parts exhibited significance anti-oxidant activity (98\%) as compared to vitamin $\mathrm{E}$.
\end{abstract}

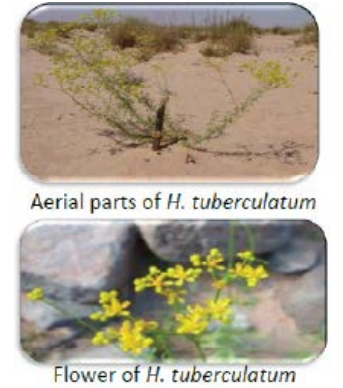

Flower of H. tuberculatum

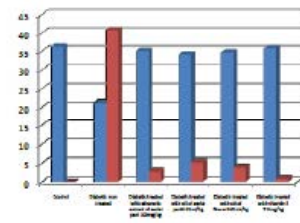

Ant-oxidant activity

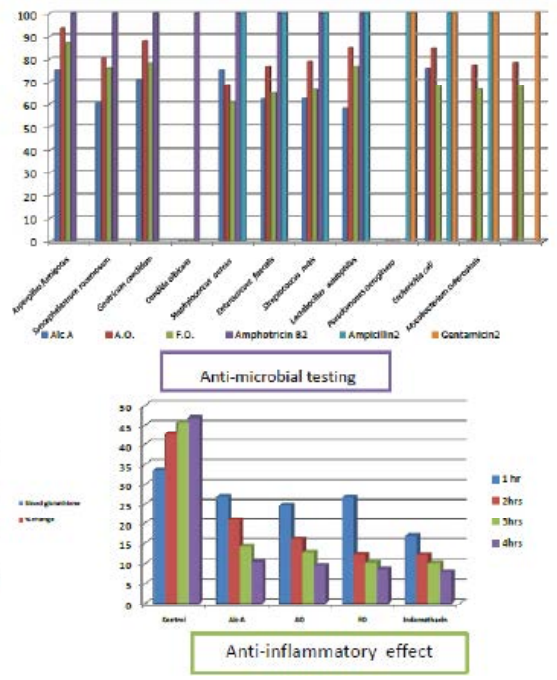

Keywords: Haplophyllum tuberculatum; Anti-fungal; Antiinflammatory; Anti-oxidant

\section{Introduction}

About 70 species of the genus Haplophyllum are present in the Mediterranean region [1]. In Egypt, the flowering aerial parts are used as a decoction for rheumatic pains [2]. In Oman, the leaves are used for relieving arthritis and also used for treatment of skin infections [3]. The plant is well known for its richness in alkaloids, fixed oils, volatile oils and furanocoumarins $[4,5]$. The ethanol extract of $H$. tuberculatum aerial parts, rich in phenolic compounds, was found to be active as anti-oxidant and radical scavenger ameliorating ROS-related processes and diseases as neurodegenerative disorders [6]. No published report concerning the potential biological activities of the volatile oil of the aerial and the flower of Libyan $H$. tuberculatum. The aim of the study is to screen certain biological activities of the ethanolic extract of the aerial parts and essential oils of Libyan $H$. tuberculatum.

\section{Materials and Methods}

\section{Plant material}

Samples of the aerial parts and flowers of Haplophyllum tuberculatum were obtained from Benghazi, Libya. Collected samples were identified by Dr. Reem Samir Hamdy, Lecturer of Plant Taxonomy, Botany Department, Faculty of Science, Cairo University, Giza, Egypt. A voucher specimen of the aerial parts and the flowers of $H$. tuberculatum, were kept in the Department of Pharmacognosy herbarium, Faculty of Pharmacy, Cairo University as a reference material specimen No. 2015224.

\section{Preparation and characterization of the tested sample}

Fresh samples of aerial parts and flowers of $H$. tuberculatum (500 g) were subjected separately to hydro-distillation. The percentage

*Corresponding author: Omar M Sabry, Pharmacognosy Department, Faculty of Pharmacy, Cairo University, Kasr El-Einy Street, 11562, Cairo, Egypt, Tel: +20224013542; E-mail: omar.sabry@cu.edu.eg

Received January 09, 2016; Accepted February 16, 2016; Published February 22, 2016

Citation: Sabry OM, El Sayed AM, Sleem AA (2016) Potential Anti-Microbial, AntiInflammatory and Anti-Oxidant Activities of Haplophyllum tuberculatum Growing in Libya. J Pharmacogn Nat Prod 2: 116. doi:10.4172/2472-0992.1000116

Copyright: @ 2016 Sabry OM, et al. This is an open-access article distributed under the terms of the Creative Commons Attribution License, which permits unrestricted use, distribution, and reproduction in any medium, provided the original author and source are credited. 
yield was calculated on the basis of the dry weight $(\mathrm{v} / \mathrm{w})$ according to The Egyptian Pharmacopoeia [7-9]. The essential oils were dried over anhydrous sodium sulfate and kept refrigerated. The air-dried powdered aerial parts of $H$. tuberculatum $(500 \mathrm{~g})$ were extracted by cold percolation with $95 \%$ ethanol $(5 \times 1 \mathrm{~L})$ till exhaustion. The ethanol extract was evaporated under reduced pressure to give $20 \mathrm{~g}$ greenish brown semi-solid residue. The solvent-free dried residue was dissolved in distilled water containing few drops of Tween 80 to yield a concentration of $5 \% \mathrm{w} / \mathrm{v}$.

\section{Testing the antimicrobial activity}

Microrganisms: The antimicrobial activity was performed against selected eight bacterial and four fungal strains of standard properties. These were maintained in the regional center for mycology and biotechnology, Al Azhar University. The tested Gram positive bacteria were Staphylococcus aureus (RCMB 010028), Enterococcus faecalis (RCMB 010084), Streptococcus mitis (RCMB 010039), Lactobacillus acidophilus (RCMB 010094) and Methicillin-resistant Staphylococcus aureus [MRSA] (RCMB 010028). The Gram negative bacteria included Pseudomonas aeruginosa (RCMB 010043), Escherichia coli (RCMB 010052) and Mycobacterium tuberculosis (RCMB 010120) and fungi [Aspergillus fumigates (RCMB 02568), Syncephalastrum racemosum (RCMB 05922), Geotricum candidum (RCMB 05097) and Candida albicans (RCMB 05036)]. Bacteria were sub-cultured on nutrient agar medium (Oxoid laboratories, UK) and fungi on Sabouraud's dextrose agar (Oxoid laboratories, UK). The essential oils were separately tested against the selected strains at concentration of $1 \mathrm{mg} / \mathrm{ml}$ adopting agar well diffusion assay method as described by Holder and Boyce (1994) [8]. Ampicillin, gentamycin, and vancomycin were used as a positive control for bacterial strain antibacterial standards, Sedico Pharmaceutical Co., 6 October City, Egypt; amphotericin B was used as a positive control anti-fungal standard, Sedico Pharmaceutical Co., 6 October City, Egypt. The plates were done in triplicate. Bacterial cultures were incubated at $37^{\circ} \mathrm{C}$ for $24 \mathrm{~h}$ while the other fungal cultures were incubated at $\left(25\right.$ to $30^{\circ} \mathrm{C}$ ) for 3-7 days. Results are recorded (Table 1) as Mean zone of inhibition in $\mathrm{mm} \pm$ Standard deviation beyond well diameter $(6 \mathrm{~mm})$ produced on a range of environmental and clinically pathogenic microorganisms using $(1 \mathrm{mg} / \mathrm{ml})$ concentration of tested samples [9].

Minimum Inhibitory Concentration (MIC) Determination: The Minimum Inhibitory Concentration (MIC) of the samples was estimated for each of the tested organism in triplicates (Table 2). Varying concentrations of the samples $(1000-0.007 \mu \mathrm{g} / \mathrm{ml})$, nutrient broth were added and then a loopful of the test organism previously diluted to $0.5 \mathrm{McF}$ arland turbidity standard was introduced to the tubes. A tube containing broth media only was seeded with the test organisms to serve as control. Tubes containing tested organisms cultures were then incubated at $37^{\circ} \mathrm{C}$ for $24 \mathrm{~h}$ while the other fungal cultures were incubated at $\left(25\right.$ to $\left.30^{\circ} \mathrm{C}\right)$ for 3-7 days. The tubes were then examined for growth by observing for turbidity [10].

Pharmacological screening: Experimental animal's adult male albino rats of Sprague Dawely Strain weighing 130-150 g were used for testing of anti-inflammatory and anti-oxidant activities (according to the ethics of the animal-breeding unit of National Research Center, ElDokki, Giza, Egypt). All animals were kept on standard laboratory diet under hygienic conditions. Water was supplied ad libitum.

Determination of median lethal dose $\mathrm{LD}_{50}$ : The $\mathrm{LD}_{50}$ of the volatile oils was determined according to the procedures developed by Karber (1941) [11].
Acute anti-inflammatory activity: It was determined according to the rat paw oedema methods [12]. Five groups of male albino rats were used ( 6 animals each). The first group received $1 \mathrm{ml}$ saline orally (negative control). The second group was given indomethacin orally (positive control). The other groups received the tested samples in the dose given in Table 3. Drugs were orally administered $1 \mathrm{hr}$ prior to carrageenan injection. Oedema was induced in the rat right hind paw by S.C. injection of $0.1 \mathrm{ml}$ of $1 \%$ carrageenan suspension in saline while $0.1 \mathrm{ml}$ saline was injected in the left hind paw. Thickness of the right hind paw $(\mathrm{mm})$ was measured immediately before and 1,2, 3 and $4 \mathrm{hr}$ post carrageenan injection with a micrometer caliber. Both paws were excised and weighed separately using an electric balance. The mean response (increase in the paw oedema) after acute inflammation and the percentage of oedema inhibition (\% of change) was calculated and results are listed (Table 3 ).

Anti-oxidant activity: The anti-oxidant activity was calculated by the determination of glutathione in blood of alloxan-induced diabetic rats adopting the methods of Beutler et al. [13] using vitamin $\mathrm{E}$ as a positive control. The animals were divided into 5 groups ( 6 animals each). One group was kept as a negative control while for the other groups, diabetes mellitus was induced according to the methods described by Eliasson and Samet [14] in which a single dose of $150 \mathrm{mg}$ alloxan/kg body weight was injected intra-peritoneal in each animal followed by an overnight fasting. A group of diabetic rats was kept nontreated, another group received daily the reference drug (Vitamin E) and the other groups received the tested samples of $H$. tuberculatum daily in the given doses (Table 4). Blood samples were taken after a week for the determination of glutathione. The results obtained were recorded in Table 4.

Drugs and chemicals: Discs of Ampicillin, Gentamycin, Vancomycin and Amphotericin B $5 \mu \mathrm{g} /$ disc, Oxoid Chemical Co., UK Carrageenan: Sigma Co. $(0.1 \mathrm{ml}$ of $1 \%$ solution, to induce inflammation), indomethacin: Epico, A.R.E. $(20 \mathrm{mg} / \mathrm{kg}$ b. wt., standard anti-inflammatory), Alloxan: Sigma Co., Vitamin E (dla-tocopheryl acetate): Pharco Pharmaceutical Co. Biochemical kits: Biodiagnostic glutathione kit.

Statistical analysis: All data were expressed as mean \pm SE and the statistical significance was evaluated using the ANOVA test followed by Duncan's multiple range tests. A probability value of less than 0.05 was considered statistically significant $(\mathrm{P}<0.05$ was considered statistically significant).

\section{Results}

Hydrodistillation of the aerial parts and flowers of $H$. tuberculatum yielded 0.4 and $1.5 \% \mathrm{v} / \mathrm{w}$ respectively of clear yellow colored oil exhibiting a characteristic agreeable odor. The total yield of the hydrodistillation of the flowers was about 3 times in the aerial parts. The specific gravity and refractive index were $0.975,0.968$ and 1.487 , 1.495 .

\section{Anti-microbial activity}

When screened for anti-microbial activity, the essential oil of the aerial parts (AO) and flowers (FO) of $H$. tuberculatum exhibited a significant effect against all tested Gram -ve and Gram +ve microorganisms (at concentration of $1 \mathrm{mg} / \mathrm{ml}$ ) and all are inactive against Pseudomonas aeruginosa. This means that they were resistant to our samples or that they necessitated the use of higher concentrations as compared to the standard antibacterial drug Gentamicin (Table 1). The essential oil of the flowers showed lower inhibition zones than 
Citation: Sabry OM, El Sayed AM, Sleem AA (2016) Potential Anti-Microbial, Anti-Inflammatory and Anti-Oxidant Activities of Haplophyllum tuberculatum Growing in Libya. J Pharmacogn Nat Prod 2: 116. doi:10.4172/2472-0992.1000116

the essential oil of the aerial parts compared to standard antibiotics (Table 1). The most sensitive microorganism is Escherichia coli its sensitivity ranged from $67.7 \%$ to $84.7 \%$ of the standard reference Gentamicin. Escherichia coli were inhibited by the essential oil of the aerial parts with MICs $3.9 \mu \mathrm{g} / \mathrm{ml}$. However, the essential oil of the aerial parts displayed a remarkable growth inhibitory effect against the fungus Aspragillus fumigates (93.6\%); Geotricum candidum (88.1\%) and a lower one on Syncephalastrum racemosum (80.2\%) where all are inactive against Candida albicans as compared to the standard anti-fungal drug Amphotricin B. The MIC of the essential oil of the aerial parts for the tested Aspergillus fumigates, Syncephalastrum racemosum and Geotricum candidum was $0.49,1.95$ and $0.12(\mu \mathrm{g} / \mathrm{ml})$. The antibacterial effect of the oil of the aerial parts may be attributed to its monoterpenes constituents. The antibacterial mechanism of oxygenated monoterpenes against $E$. coli and S. aureus might attributable to its hydrophobicity [15]. The volatile oils were slightly more effective against Gram positive than Gram negative bacteria. This is in agreement with observations made by other authors that Gram positive bacteria were more susceptible to essential oils than Gram negative ones [16]. Results showed that the essential oil of the aerial

\begin{tabular}{|c|c|c|c|c|}
\hline Tested microorganisms & Alc A & AO & F O & Standared anti-microbial \\
\hline FUNGI & & & & Amphotericin B \\
\hline Aspergillus fumigatus (RCMB 02568) & $\begin{array}{l}17.8 \pm 0.58 \\
75.1 \%\end{array}$ & $\begin{array}{l}22.2 \pm 0.44 \\
93.6 \%\end{array}$ & $\begin{array}{l}20.6 \pm 0.58 \\
86.9 \%\end{array}$ & $\begin{array}{l}23.7 \pm 0.1 \\
100 \%\end{array}$ \\
\hline Syncephalastrum racemosum (RCMB 05922) & $\begin{array}{l}15.3 \pm 0.44 \\
60.2 \%\end{array}$ & $\begin{array}{l}20.4 \pm 0.58 \\
80.3 \%\end{array}$ & $\begin{array}{l}19.3 \pm 0.25 \\
75.9 \%\end{array}$ & $\begin{array}{l}25.4 \pm 0.1 \\
100 \%\end{array}$ \\
\hline Geotricum candidum (RCMB 05097) & $\begin{array}{l}20.3 \pm 0.25 \\
70.7 \%\end{array}$ & $\begin{array}{l}25.3 \pm 0.37 \\
88.1 \%\end{array}$ & $\begin{array}{l}22.4 \pm 0.38 \\
78.0 \%\end{array}$ & $\begin{array}{l}28.7 \pm 0.2 \\
100 \%\end{array}$ \\
\hline Candida albicans (RCMB 05036) & NA & NA & NA & $19.8 \pm 0.2$ \\
\hline Gram Positive Bacteria & & & & Ampicillin \\
\hline Staphylococcus aureus (RCMB 010028) & $\begin{array}{l}20.6 \pm 0.63 \\
75.1 \%\end{array}$ & $\begin{array}{l}18.7 \pm 0.44 \\
68.2 \%\end{array}$ & $\begin{array}{l}16.6 \pm 0.44 \\
60.5 \%\end{array}$ & $\begin{array}{l}27.4 \pm 0.18 \\
100 \%\end{array}$ \\
\hline Enterococcus faecalis [RCMB 010084(6)] & $\begin{array}{l}16.4 \pm 0.44 \\
62.1 \%\end{array}$ & $\begin{array}{l}20.2 \pm 0.25 \\
76.5 \%\end{array}$ & $\begin{array}{l}17.1 \pm 0.25 \\
64.7 \%\end{array}$ & $\begin{array}{l}26.4 \pm 0.34 \\
100 \%\end{array}$ \\
\hline Streptococcus mitis (RCMB 010039) & $\begin{array}{l}15.2 \pm 1.2 \\
62.5 \%\end{array}$ & $\begin{array}{l}19.2 \pm 0.63 \\
79.0 \%\end{array}$ & $\begin{array}{l}16.1 \pm 0.63 \\
66.2 \%\end{array}$ & $\begin{array}{l}24.3 \pm 0.44 \\
100 \%\end{array}$ \\
\hline Lactobacillus acidophilus (RCMB 010094) & $\begin{array}{l}14.6 \pm 0.44 \\
57.9 \%\end{array}$ & $\begin{array}{l}21.4 \pm 0.58 \\
84.9 \%\end{array}$ & $\begin{array}{l}19.3 \pm 0.44 \\
76.5 \%\end{array}$ & $\begin{array}{l}25.2 \pm 0.58 \\
100 \%\end{array}$ \\
\hline Gram negativeBacteria & & & & Gentamicin \\
\hline Pseudomonas aeruginosa (RCMB 010043) & NA & NA & NA & $\begin{array}{l}17.3 \pm 0.15 \\
100 \%\end{array}$ \\
\hline Escherichia coli (RCMB 010052) & $\begin{array}{l}16.9 \pm 0.63 \\
75.7 \%\end{array}$ & $\begin{array}{l}18.9 \pm 0.58 \\
84.7 \%\end{array}$ & $\begin{array}{l}15.1 \pm 0.63 \\
67.7 \%\end{array}$ & $\begin{array}{l}22.3 \pm 0.18 \\
100 \%\end{array}$ \\
\hline Mycobacterium tuberculosis (RCMB 010120) & NA & $\begin{array}{l}14.2 \pm 0.63 \\
77.1 \%\end{array}$ & $\begin{array}{l}12.2 \pm 0.58 \\
66.3 \%\end{array}$ & $\begin{array}{l}18.4 \pm 0.58 \\
100 \%\end{array}$ \\
\hline G +ve bacteria & & & & Vancomycin \\
\hline $\begin{array}{l}\text { Methicillin-resistant Staphylococcus aureus [MRSA] (RCMB } \\
010028 \text { (3) }\end{array}$ & NA & $\begin{array}{l}15.4 \pm 1.2 \\
78.5 \%\end{array}$ & $\begin{array}{l}13.3 \pm 0.63 \\
67.8 \%\end{array}$ & $\begin{array}{l}19.6 \pm 0.58 \\
100 \%\end{array}$ \\
\hline
\end{tabular}

NA: no action

Mean zone of inhibition in $\mathrm{mm} \pm$ Standard deviation beyond well diameter $(6 \mathrm{~mm})$ produced on a range of environmental and clinically pathogenic microorganisms using $(1 \mathrm{mg} / \mathrm{ml})$ concentration of tested samples

Table 1: Results of the anti-microbial testing of the ethanol extract and essential oils of $H$. tuberculatum.

\begin{tabular}{|c|c|c|c|c|}
\hline Sample & Alc A & A O & FO & Standared anti-microbial \\
\hline Tested microorganisms & & \multicolumn{2}{|c|}{ Minimum inhibitory concentration $(\mu \mathrm{g} / \mathrm{ml})$} & Amphotericin B \\
\hline Aspergillus fumigatus (RCMB 02568) & 7.81 & 0.49 & 1.95 & 0.12 \\
\hline Syncephalastrum racemosum (RCMB 05922) & 62.5 & 1.95 & 3.9 & 0.12 \\
\hline Geotricum candidum (RCMB 05097) & 1.95 & 0.12 & 0.49 & 0.06 \\
\hline Candida albicans (RCMB 05036) & NA & NA & NA & 1.95 \\
\hline Gram Positive Bacteria: & & & & Ampicillin \\
\hline Staphylococcus aureus (RCMB 010028) & 1.95 & 7.81 & 31.25 & 0.06 \\
\hline Enterococcus faecalis [RCMB $010084(6)]$ & 31.25 & 1.95 & 15.63 & 0.03 \\
\hline Streptococcus mitis (RCMB 010039) & 62.5 & 3.9 & 31.25 & 0.12 \\
\hline Lactobacillus acidophilus(RCMB 010094) & 62.5 & 0.98 & 3.9 & 0.03 \\
\hline Gram negative Bacteria & & & & Gentamicin \\
\hline Pseudomonas aeruginosa (RCMB 010043) & NA & NA & NA & 15.63 \\
\hline Escherichia coli (RCMB 010052) & 15.63 & 3.9 & 62.5 & 0.49 \\
\hline Mycobacterium tuberculosis (RCMB 010120) & NA & 62.5 & 125 & 7.81 \\
\hline G +ve bacteria & & & & Vancomycin \\
\hline $\begin{array}{l}\text { Methicillin-resistant } \\
\text { Staphylococcus aureus [MRSA] (RCMB } 010028 \text { (3)) }\end{array}$ & NA & 62.5 & 125 & 1.95 \\
\hline
\end{tabular}

Table 2: Anti-microbial Activity of oils as MICS $(\mu \mathrm{g} / \mathrm{ml})$ of tested samples against standard amphotericin B. 
Citation: Sabry OM, El Sayed AM, Sleem AA (2016) Potential Anti-Microbial, Anti-Inflammatory and Anti-Oxidant Activities of Haplophyllum tuberculatum Growing in Libya. J Pharmacogn Nat Prod 2: 116. doi:10.4172/2472-0992.1000116

Page 4 of 5

\begin{tabular}{|c|c|c|c|c|c|c|c|c|c|c|}
\hline \multirow{2}{*}{\begin{tabular}{|l|} 
Time (hour) \\
Group
\end{tabular}} & \multirow[t]{2}{*}{ Dose } & \multirow{2}{*}{\begin{tabular}{|l|}
\multicolumn{1}{|c|}{ Zero } \\
$\begin{array}{l}\text { Paw diameter } \\
(\mathrm{mm})\end{array}$ \\
\end{tabular}} & \multicolumn{2}{|l|}{1} & \multicolumn{2}{|c|}{2} & \multicolumn{2}{|c|}{3} & \multicolumn{2}{|c|}{4} \\
\hline & & & $\begin{array}{l}\text { Paw diameter }(\mathrm{mm}) / \\
\mathrm{a}(\% \text { of change })\end{array}$ & $\begin{array}{l}\text { Oedema } \\
\text { thickness } \\
(\mathrm{mm})\end{array}$ & $\begin{array}{l}\text { Paw diameter } \\
(\mathrm{mm}) / \mathrm{a}(\% \text { of } \\
\text { change })\end{array}$ & $\begin{array}{l}\text { Oedema } \\
\text { thickness } \\
(\mathrm{mm})\end{array}$ & $\begin{array}{l}\text { Paw diameter } \\
(\mathrm{mm}) / \mathrm{a}(\% \text { of } \\
\text { change })\end{array}$ & $\begin{array}{l}\text { Oedema } \\
\text { thickness } \\
(\mathrm{mm})\end{array}$ & $\begin{array}{l}\text { Paw diameter } \\
(\mathrm{mm}) / \mathrm{a}(\% \text { of } \\
\text { change })\end{array}$ & $\begin{array}{l}\text { Oedema } \\
\text { thickness } \\
(\mathrm{mm})\end{array}$ \\
\hline Control & $1 \mathrm{ml}$ saline & $3.30 \pm 0.08$ & $4.41 \pm 0.1^{*} /(33.63)$ & 1.11 & $\begin{array}{l}4.71 \pm 0.13^{*} / \\
(42.72)\end{array}$ & 1.41 & $\begin{array}{l}4.81 \pm 0.12^{*} / \\
(45.75)\end{array}$ & 1.51 & $\begin{array}{l}4.85 \pm 0.08^{*} / \\
(46.96)\end{array}$ & 1.55 \\
\hline Alc A & $100 \mathrm{mg} / \mathrm{kg}$ & $3.45 \pm 0.08$ & $\begin{array}{l}4.38 \pm 0.10 * / \\
(26.95)\end{array}$ & 0.93 & $\begin{array}{l}4.17 \pm 0.13^{*} / \\
(20.86)\end{array}$ & 0.72 & $\begin{array}{l}3.94 \pm 0.12 * / \\
(14.20)\end{array}$ & 0.49 & $\begin{array}{l}3.81 \pm-0.08^{*} / \\
(10.43)\end{array}$ & 0.36 \\
\hline $\mathrm{AO}$ & $0.01 \mathrm{ml} / \mathrm{kg}$ & $3.57 \pm 0.10$ & $4.45 \pm 0.14^{*} /(24.65)$ & 0.88 & $\begin{array}{l}4.14 \pm 0.14^{*} / \\
(15.96)\end{array}$ & 0.57 & $\begin{array}{l}4.02 \pm 0.14^{*} / \\
(12.60)\end{array}$ & 0.45 & $\begin{array}{l}3.91 \pm 0.11^{*} / \\
(9.52)\end{array}$ & 0.34 \\
\hline $\mathrm{FO}$ & $0.01 \mathrm{ml} / \mathrm{kg}$ & $3.62 \pm 0.11$ & $4.59 \pm 0.20^{*} /(26.79)$ & 0.97 & $\begin{array}{l}4.06 \pm 0.10^{*} / \\
(12.15)\end{array}$ & 0.44 & $\begin{array}{l}3.99 \pm 0.05^{*} / \\
(10.22)\end{array}$ & 0.37 & $\begin{array}{l}3.93 \pm 0.03^{*} / \\
(8.56)\end{array}$ & 0.31 \\
\hline Indomethacin & $20 \mathrm{mg} / \mathrm{Kg}$ & $3.56 \pm 0.08$ & $4.16 \pm 0.09^{*} /(16.85)$ & 0.6 & $\begin{array}{l}3.99 \pm 0.06^{*} / \\
(2.07)\end{array}$ & 0.43 & $\begin{array}{l}3.92 \pm 0.01^{*} / \\
(10.11)\end{array}$ & 0.36 & $\begin{array}{l}3.84 \pm 0.01^{*} / \\
(7.85)\end{array}$ & 0.28 \\
\hline
\end{tabular}

* Significantly different from zero time at $\mathrm{p}<0.05$. Dose in $\mathrm{mg}, \mathrm{ml} / \mathrm{kgb} . \mathrm{wt}$

a\% oedema inhibition (\% of change) $=\left(M_{c}-M_{t}\right) \times 100 / M_{c}$;

$M_{c}$ is the mean oedema in control animals; $M_{t}$ is the mean oedema in drug-treated animals

Table 3: Effect of the ethanol extracts of $H$. tuberculatum and indomethacin on carrageenan- induced hind paw oedema in male albino rats $(n=6)$.

\begin{tabular}{|l|l|l|l|}
\hline Group & $\begin{array}{l}\text { Blood glutathione } \\
\text { (mg \%) }\end{array}$ & \% of Change & \% Potency \\
\hline Control (1 ml saline) & $36.2 \pm 1.4$ & - & - \\
\hline Diabetic non treated & $21.4 \pm 0.5^{*}$ & 40.88 & - \\
\hline $\begin{array}{l}\text { Diabetic treated with Alc A } \\
(100 \mathrm{mg} / \mathrm{kg})\end{array}$ & $35.1 \pm 1.2^{*}$ & 3.03 & 98.04 \\
\hline $\begin{array}{l}\text { Diabetic treated with AO }(0.01 \\
\mathrm{ml} / \mathrm{Kg})\end{array}$ & $34.2 \pm 0.9^{*}$ & 5.52 & 95.5 \\
\hline $\begin{array}{l}\text { Diabetic treated with FO }(0.01 \\
\mathrm{ml} / \mathrm{Kg})\end{array}$ & $34.7 \pm 0.8^{*}$ & 4.14 & 96.9 \\
\hline $\begin{array}{l}\text { Diabetic treated with Vitamin } \\
\mathrm{E}(7.5 \mathrm{mg} / \mathrm{Kg})\end{array}$ & $35.8 \pm 1.3^{*}$ & 1.10 & 100 \\
\hline
\end{tabular}

*Statistically significant different from control group at $p<0.01$

b\% of change from control $=\left(M_{c}-M_{t}\right) \times 100 / M_{c}$;

$M_{c}$ is the mean change in control animals; $M_{t}$ is the mean change in drug-treated animals; c \% Potency calculated as regard the standard drug

Table 4: Anti-oxidant activity of the ethanol extracts and essential oils of $H$. tuberculatum in male albino rats $(n=6)$.

parts was much more active against the twelve tested microorganisms than the essential oil of the flowers. The essential oil of the aerial parts inhibit growth of Mycobacterium tuberculosis and Methicillin-resistant Staphylococcus aureus $(77.10 \%)$ and $(78.50 \%)$ respectively compared to standard antibiotics (Table 2). The alcoholic extract of the aerial parts presented $75 \%$ potency as antibacterial agent on Staphylococcus aureus and Escherichia coli (MIC 1.95 and $15.63 \mu \mathrm{g} / \mathrm{ml}$ ).

\section{LD50}

The 24- hours $\mathrm{LD}_{50}$ was approximately more than $0.05 \mathrm{ml}, 10 \mathrm{~g} / \mathrm{kg}$ b.wt. the essential oils and the ethanolic extract of aerial parts (Alc. A). These results showed that the essential oils and the ethanolic extract are safe and non-toxic.

\section{Anti-inflammatory activity}

The essential oil of the aerial parts of H. tuberculatum exhibited a remarkable acute anti-inflammatory activity against carrageenan induced oedema in rats, when compared to the standard drug (Table 3). Percentage of oedema inhibition of the essential oil of the aerial parts, the essential oil of the flowers and the ethanolic extract of the aerial parts were 9.52, 8.56 and 10.43 and was found to be comparable to the standard drug at the selected dose.

\section{Anti-oxidant activity}

The ethanolic extract of the aerial parts exhibited significant antioxidant activity (98\%). Recorded results (Table 4) revealed also that the

essential oils exerted a remarkable anti-oxidant activity. The reduced level of glutathione in diabetic rats was greatly restored by the essential oils of the aerial parts and flowers relative to vitamin E (potency 100\%), so they could be considered as powerful anti-oxidants.

\section{Discussion}

To the best of our knowledge, this is the first report on the potential biological activities of the alcoholic extract and essential oil of Libyan H. tuberculatum.

Anti-microbial activity of essential oil is difficult to correlate to a specific compound due to their complexity and variability and in general, is attributed to phenolic and hydroxyl groups. Although other active terpenes, alcohols, aldehydes and esters can contribute to the overall anti-microbial effect of essential oils [17]. The mechanism of action of essential oils against bacteria has now been partly elucidated. Prior to the availability of data, assumptions about its mechanism of action were made on the basis of its hydrocarbon structure and lipophilicity. Since hydrocarbons partition preferentially enter into biological membranes and disrupt their vital functions [18]. Oils of $H$. tuberculatum were also presumed to behave in this manner. Most of the anti-microbial activity in essential oils is found in the oxygenated terpenoids (e.g., alcohols and phenolic terpenes); while some hydrocarbons also exhibit anti-microbial effects [19-21]. Accepted mechanisms of anti-microbial interaction that produce synergism include the sequential inhibition of a common biochemical pathway, inhibition of protective enzymes and use of cell wall active agents to enhance the uptake of other anti-microbials [22].

Monoterpenes (terpinen-4-ol and a-terpineol) may act in vivo to diminish the normal inflammatory response [23]. Terpinen-4-ol modulates the vasodilation and plasma extravasation associated with histamine-induced inflammation in humans [24]. $\boldsymbol{\gamma}$-Terpinene, as major monoterpene hydrocarbon reported in oil of $H$. tuberculatum [25], retards the peroxidation of linoleic acid. Anti-oxidant mechanism of $H$. tuberculatum is completely different from the mechanism of antioxidant action of vitamin $\mathrm{E}$ [26].

\section{Conclusion}

The essential oil of the aerial parts of $H$. tuberculatum inhibit growth of Mycobacterium tuberculosis and Methicillin-resistant Staphylococcus aureus $(77.10 \%)$ and $(78.50 \%)$ compared to standard antibiotics. The alcoholic extract of the aeial parts presented $75 \%$ potency as antibacterial agent on Staphylococcus aureus and Escherichia 
Citation: Sabry OM, El Sayed AM, Sleem AA (2016) Potential Anti-Microbial, Anti-Inflammatory and Anti-Oxidant Activities of Haplophyllum tuberculatum Growing in Libya. J Pharmacogn Nat Prod 2: 116. doi:10.4172/2472-0992.1000116

Page 5 of 5

coli (MIC 1.95 and $15.63 \mu \mathrm{g} / \mathrm{ml}$ ). The essential oil of the aerial parts of $H$. tuberculatum exhibited a remarkable acute anti-inflammatory activity against carrageenan induced oedema in rats, when compared to the standard drug. The reduced level of glutathione in diabetic rats was greatly restored by the essential oils of the aerial parts and flowers relative to vitamin E (potency $100 \%$ ), so they could be considered as powerful anti-oxidants.

\section{References}

1. Willis JC (1980) A Dictionary of Flowering Plants and Ferns. ( $8^{\text {th }}$ edn) Cambridge University Press, Cambridge.

2. Batanouny KH, Abou Tabl S, Shabana M, Soliman F (1999) Plants of potential medicinal value. In: Wild medicinal plants in Egypt. Swiss Development Cooperation (SDC), Switzerland.

3. Mossa JS, Al-Yahya MA, Al-Meshal IA (1987) Medical Plants of Saudi Arabia, King Saud University Libraries, Riyadh.

4. Ulubelen A and Öztürk M (2008) Alkaloids, coumarins and lignans from Haplophyllum species. Rec Nat Prod 2: 54-69.

5. Diar A, Jawad E, Al-Khateeb E, Al-Shamma A (2005) Qualitative and Quantitative investigations of Furocoumarin derivatives (Psoralens) Haplophyllum tuberculatum of (Rutaceae). AJPS 1-13.

6. Eissa TF, González-Burgos E, Carretero ME, Gómez-Serranillos MP (2014) Biological activity of HPLC-characterized ethanol extract from the aerial parts of Haplophyllum tuberculatum. Pharm Biol 52: 151-156.

7. The Egyptian Pharmacopoeia (2005) Central Administration of Pharmaceutical Affairs (CAPA) (4th edn) Ministry of Health and Population, Egypt.

8. Holder IA, Boyce ST (1994) Agar well diffusion assay testing of bacteria susceptibility to various anti-microbials in concentrations non-toxic for human cells in culture. Burns 20: 426-469.

9. Agwa H, Aly MM, Bonaly R (2000) Isolation and characterization of two Streptomyces species produced non polyenic anti-fungal agents. J Union Arab Biol 7: 62-82.

10. Doughari JH (2006) Anti-microbial Activity of Tamarindus indica Linn. Trop J Pharm Res 5: 597-603

11. Karber G (1941) Pharmacologische methods to detect From Arzneimittein and Giffter and analysis Wissenschoftliche, Gess Publisher, Russia.

12. Winter CA, Risley EA, Nuss GW (1962) Carrageenin-induced edema in hind paw of the rat as an assay for antiiflammatory drugs. Proc Soc Exp Biol Med 111: $544-547$.
13. Beutler E, Duron O, Kelly BM (1963) Improved method for the determination of blood glutathione. J Lab Clin Med 61: 882-888.

14. Eliasson SG, Samet JM (1969) Alloxan induced neuropathies: lipid changes in nerve and root fragments. Life Sci 8: 493-498.

15. Lei J, Yu J, Yu H, Liao Z (2008) Composition, cytotoxicity and anti-microbial activity of essential oil from Dictamnus dasycarpus. Food Chem 107:12051209.

16. Sassi AB, Harzallah-Skhiri F, Chraief I, Bourgougnon N, Hammami M, et al (2008) Chemical composition and anti-microbial activities of the essential oil of (Tunisian) Chrysanthemum trifurcatum (Desf.) Batt. and Trab. flowerheads. C R Chimie 11: 324-330.

17. Belletti N, Ndagijimana M, Sisto C, Guerzoni ME, Lanciotti R, et al. (2004) Evaluation of the antimicrobial activity of citrus essences on Saccharomyces cerevisiae. J Agric Food Chem 52: 6932-6938.

18. Sikkema J, de Bont JA, Poolman B (1995) Mechanisms of membrane toxicity of hydrocarbons. Microbiol Rev 59: 201-222.

19. Burt S (2004) Essential oils: their antibacterial properties and potential applications in foods--a review. Int J Food Microbiol 94: 223-253.

20. Koroch A, Juliani HR, Zygadlo JA (2007) Bioactivity of Essential Oils and Their Components. In: Berger, Ralf Gunter (eds) Flavours and Fragrances Chemistry Bioprocessing and Sustainability. (1stedn) Springer Verlag, Germany.

21. Delaquis PJ, Stanich K, Girard B, Mazza G (2002) Antimicrobial activity of individual and mixed fractions of dill, cilantro, coriander and eucalyptus essential oils. Int J Food Microbiol 74: 101-109.

22. Santiesteban-López, Palou E, López-Malo A (2007) Susceptibility of foodborne bacteria to binary combinations of antimicrobials at selected $a(w)$ and pH. J Appl Microbiol 102: 486-497.

23. Brand C, Grimbaldeston MA, Gamble JR, Drew J, Finlay-Jones JJ, et al. (2002) Tea tree oil reduces the swelling associated with the efferent phase of a contact hypersensitivity response. Inflamm Res 51: 236-244.

24. Khalil Z, Pearce AL, Satkunanathan N, Storer E, Finlay-Jones JJ, et al. (2004) Regulation of wheal and flare by tea tree oil: complementary human and rodent studies. J Invest Dermatol 123: 683-690.

25. Sabry OMM, El sayed A (2016) GC/MS and cytotoxic potentiality of essential oil of Haplophyllum tuberculatum growing in Libya. Pharmacog J 8:1-4.

26. Foti MC, Ingold KU (2003) Mechanism of inhibition of lipid peroxidation by gamma-terpinene, an unusual and potentially useful hydrocarbon antioxidant. J Agric Food Chem 51: 2758-2765. 